Check for updates

Cite this: RSC Adv., 2017, 7, 56296 Accepted 7th December 2017

DOI: 10.1039/c7ra10517g

rsc.li/rsc-advances
Received 22nd September 2017

\section{Novel type ketone-substituted metallophthalocyanines: synthesis, spectral, structural, computational and anticancer studies}

\author{
Ceylan Hepokur, ${ }^{a}$ Armağan Günsel, ${ }^{\mathrm{b}}$ M. Nilüfer Yarasir, (D) ${ }^{\mathrm{b}}$ Ahmet T. Bilgiçli, (DD *b \\ Burak Tüzün, ${ }^{c}$ Gamze Tüzün ${ }^{a}$ and İlhan Yaylim ${ }^{d}$
}

\begin{abstract}
This work reports on the synthesis and characterization of phthalocyanines (M= CU(I) (2), Zn(II) (3) $\ln ($ III) (4) and Co(॥) (5)) peripherally tetra-substituted with 1-(4-hydroxyphenyl)propan-1-one. Confirmation of the synthesized phthalocyanine structures are performed with a combination of elemental analysis, FTIR, ${ }^{1} \mathrm{H}$ NMR, ${ }^{13} \mathrm{C}-\mathrm{NMR}$, UV-vis and MALDI-MS SEM and spectral data. Their aggregation properties were examined in THF by UV-vis. Spectral and photophysical (fluorescence quantum yield) properties of complexes (2-4) were reported in THF (tetrahydrofuran). These results suggest that the metal in the core of the phthalocyanine plays an important role in the fluorescence quantum yields $\Phi_{\mathrm{F}}$ of the synthesized complexes (2-4). Also, the anticancer activities of complexes were studied on MCF-7, MG63, and L929 cell lines. Finally, all synthesized phthalocyanines were investigated by quantum chemical studies. Chemical reactivity parameters such as $E_{\mathrm{HOMO}}, E_{\mathrm{LUMO}}, \Delta E$ (HOMO-LUMO energy gap) were calculated by Gaussian software.
\end{abstract}

\section{Introduction}

Cancer is a multi-step process in which cells undergo metabolic and behavioral changes leading to excessive and timeless proliferation. Cancer begins with rapid proliferation of cells and loss of apoptosis functions. According to the International Cancer Research Institute (IARC), an average of 14 million people are diagnosed with cancer each year and 8.2 million people die. It is estimated that 12 million people will lose their lives due to cancer in 2030. There are three basic treatment methods for cancer treatment, namely surgery, chemotherapy and radiotherapy. These three treatment methods are applied to cancer patients in combination with each other, depending on the type of cancer, its stage, its location, the general health of the patient, the sex of the patient, and some other factors. ${ }^{1}$

Phthalocyanines which are synthetic analogues of porphyrin compounds such as hemoglobin and chlorophyll, have visible optical properties and good thermal stability because of having an $18-\pi$ aromatic macrocycle. ${ }^{2}$ Since the discovery of phthalocyanines (Pcs), many scientists have aimed to synthesize/design optimal molecules for a variety of applications such as chemical

${ }^{a}$ Faculty of Pharmacy, Department of Basic Pharmaceutical Sciences, Division of Biochemistry, Cumhuriyet University, Sivas, Turkey

${ }^{b}$ Department of Chemistry, Sakarya University, TR54187 Serdivan, Sakarya, Turkey. E-mail: abilgicli@sakarya.edu.tr; Tel: +90-264-295-71-16

${ }^{c}$ Department of Chemistry, Cumhuriyet University, Sivas, Turkey

${ }^{d}$ Institute of Experimental Medicine, Department of Molecular Medicine, Istanbul, Turkey sensors, display devices, catalysts, biological imaging, and photosensitizers for photodynamic therapy (PDT). ${ }^{3-7}$ They have been explored to be effective photosensitizers for PDT owing to the strong absorption in the red visible region and high efficiency in producing reactive oxygen species (ROS), e.g. singlet oxygen $\left({ }^{1} \mathrm{O}_{2}\right)$, leading to destruction of cancer cells. The variety of metal ion that is inserted to the inner core of phthalocyanines strongly influences the ROS production. ${ }^{8}$ Especially, scientists have aimed to synthesize the phthalocyanines (Pc) that have diamagnetic ions $\left(\mathrm{Zn}^{2+}, \mathrm{Si}^{4+}, \mathrm{In}^{3+}, \mathrm{Ga}^{3+}\right.$, etc. $)$ because of high ROS yields for PDT $^{\mathbf{9}}$ such as gallium phthalocyanines (GaPcs) ${ }^{\mathbf{1 0}}$ and indium phthalocyanines (InPcs). ${ }^{11}$ The enhancement of the solubility in organic solvents is very indispensable in the applications of phthalocyanine complexes. ${ }^{12}$ For this, it is necessary to attach some functional groups at the peripheral regions of phthalocyanine ring and/or insert some metal ions to the inner core of phthalocyanines [such as Mn(III), In(III) and $\mathrm{Ga}(\mathrm{III})$ ]. The features like solubility, aggregation, absorption, photophysical and photochemical strongly depend on the functional groupsat the peripheral and/or nonperipheral regions of phthalocyanines. ${ }^{\mathbf{1 3 , 1 4}}$

George and et al. conjugated Rubus-phthalocyanine apply to MCF-7 cell line for $24 \mathrm{~h}$. Decreased cell viability was observed from $90 \%$ to $60 \% .^{15}$ Horne et al. the novel metallophthalocyanine was apply to MCF-7 cell line. They were found overall morphology averaging a viability of $>85 \% .{ }^{16}$ Ogbodu et al. studied new zinc phthalocyanine-spermine-single walled carbon nanotube conjugate on MCF-7 breast cancer cell line. 
When dosed at $40 \mu \mathrm{M}$ cell viability decreased from $100 \%$ to $75 \% .^{17}$

Aliphatic and aromatic ketones are the compounds having reactive carbonyl group. They have characteristic flavors, aromas and therapeutic properties. Many synthetic and naturally formed ketones are used in cosmetics, perfumes, food additives, and are important in a variety of medical and biological materials such as antimicrobial activity. ${ }^{14,18,19}$

Pharmaceutical industries spend billions of dollars for the development of effective agents in the diagnosis and treatment of cancer each year. Therefore, many organic based cytotoxic agents have been discovered, and they are extensively applied for treatment of cancer. ${ }^{20}$

In this paper, we have firstly submitted the synthesis and characterization of phthalocyanines ( $\mathrm{M}=\mathrm{Cu}$ (II) (2), Zn(II) (3), In(III) (4) and Co(II) (5)) substituted with 1-(4-hydroxyphenyl) propan-1-one at the non-peripheral regions to compare the effect of different metals and the functional group "aromatic ketone" in a variety of medical and biological materials such as new agent for cancer therapeutic. Also, spectral and photophysical (fluorescence quantum yield) properties of phthalocyanine complexes (2-4) were reported in THF (tetrahydrofuran). Additionally, the synthesized phthalocyanines were investigated by quantum chemical studies such as $E_{\text {HOMO }}, E_{\text {LUMO }}, \Delta E$ (HOMO-LUMO energy gap). Finally, the synthesized phthalocyanines were evaluated for anticancer activity on MCF-7, MG63, and L929 cancer cell lines.

\section{Materials and methods}

\subsection{Chemicals}

Dimethylsulfoxide (DMSO), Cell Proliferation Kit II (XTT), Dulbecco's Modified Eagle's Medium-high glucose from Sigma (St. Louis, MO, USA). Penicillin, streptomycin and trypsin from Gibco (Paisley, England), Eagle's Minimum, fetal bovine serum (FBS) from Biochrom (Berlin, Germany), phosphate buffer saline (PBS) tablet from Medicago (Uppsala, Sweden). Some chemicals such as chloroform $\left(\mathrm{CHCl}_{3}\right)$, dichloromethane $\left(\mathrm{CH}_{2} \mathrm{Cl}_{2}\right)$, tetrahydrofuran (THF), dimethylformamide (DMF), dimethyl sulfoxide (DMSO), 4-(4-hydroxyphenyl)butan-2-one, 1(4-hydroxyphenyl)propan-1-one, $\mathrm{CoCI}_{2}, \mathrm{CuCl}_{2}, \mathrm{Zn}(\mathrm{Ac})_{2}$ and $\mathrm{InCl}_{3}$ were acquired from Merck and Alfa Aesar and used as received. Cell Proliferation Kit II (XTT), Dulbecco's Modified Eagle's Medium-high glucose from Sigma (St. Louis, MO, USA). Penicillin, streptomycin and trypsin from Gibco (Paisley, England), Eagle's Minimum, fetal bovine serum (FBS) from Biochrom (Berlin, Germany), phosphate buffer saline (PBS) tablet from Medicago (Uppsala, Sweden) were purchased. UVvis spectra was acquired in a quartz cuvette on an Agilent Model 8453 diode array spectrophotometer. Fluorescence measurement were recorded by Hitachi S-7000 fluorescence spectrophotometer. Perkin-Elmer spectrum two FT-IR spectrophotometer was used to take FT-IR spectra. All the products were purified by chromatography on silica gel (Merck grade 60) from Aldrich. All reactions were achieved under a dry $\mathrm{N}_{2}$ atmosphere. A Bruker 300 spectrometer instruments was used to take ${ }^{1} \mathrm{H}$-NMR and ${ }^{13} \mathrm{C}$-NMR spectras. Mass spectras (MS) were analyzed by MALDI SYNAPT G2-Si Mass Spectrometry.

\subsection{Synthesis}

2.2.1. The synthesis of 3-(4-propionylphenoxy)phthalonitrile (1). Under $\mathrm{N}_{2}$ atmosphere, 1-(4-hydroxyphenyl)propan-1one (0.95 g, $6.35 \mathrm{mmol})$ were dissolved in dry DMF $(20 \mathrm{~mL})$ and then 3-nitrophthalonitrile $(1 \mathrm{~g}, 5.78 \mathrm{mmol})$ was put to the solution. After $10 \mathrm{~min}$, anhydrous $\mathrm{K}_{2} \mathrm{CO}_{3}(5.36 \mathrm{~g}, 38.88 \mathrm{mmol})$ was put by stirring efficiently for $2 \mathrm{~h}$. The reaction mixture was stirred under $\mathrm{N}_{2}$ at $45{ }^{\circ} \mathrm{C}$ for 3 days. Then the solution was poured into ice-water $(200 \mathrm{~mL})$. The obtained product was filtered off, firstly cleaned with water and then with diethyl ether and finally purified by chromatography over a silica gel column by using a eluent that is a mixture of $\mathrm{CH}_{2} \mathrm{Cl}_{2}$ /ethanol.

The product was soluble in $\mathrm{CHCl}_{3}, \mathrm{CH}_{2} \mathrm{Cl}_{2}$, THF, DMF and DMSO. Yield of (1): $1.17 \mathrm{~g}(65 \%) \mathrm{mp} 113{ }^{\circ} \mathrm{C}$. Anal. calcd for (\%) $\mathrm{C}_{17} \mathrm{H}_{12} \mathrm{~N}_{2} \mathrm{O}_{2}$ (276.29 $\mathrm{g} \mathrm{mol}^{-1}$ ): C, 73.90; H, 4.38; N, 10.14; found: C, 74.11; H, 4.52; N, 10.93. FT-IR $\left(\nu_{\max } / \mathrm{cm}^{-1}\right): 3079,3092(\mathrm{H}-\mathrm{Ar})$, 2982, 2939 (H-Aliph.), 2234 (CN), 1681 (C=O), 1570 (Ar C=C), 1161 (Ar-O-Ar). ${ }^{1} \mathrm{H}-\mathrm{NMR}\left(\mathrm{CDCI}_{3}\right): 7.98-7.85(\mathrm{~m}, 4 \mathrm{H}), 7.81(\mathrm{t}, 1 \mathrm{H})$, 7.45-7.30 (d, 2H), $3.12(\mathrm{~m}, 2 \mathrm{H}), 1.18(\mathrm{t}, 3 \mathrm{H}) ;{ }^{13} \mathrm{C}-\mathrm{NMR}\left(\mathrm{CDCI}_{3}\right) \delta$ : 203.5, 162.4, 157.3, 139.6, 134.1, 132.1, 124.5, 124.2, 120.7, 118.2, 116.4, 116.0, 108.7, 33.2, 8.2; MS $[\mathrm{m} / \mathrm{z}]: 315.88[\mathrm{M}+\mathrm{K}]^{+}$.

2.2.2. General procedure for the synthesis of metallo phthalocyanines (MPcs). Under a nitrogen atmosphere, a mixture of anhydrous $\mathrm{CoCl}_{2}$ or $\mathrm{CuCl}_{2}$ or $\mathrm{Zn}(\mathrm{Ac})_{2}$ or $\mathrm{InCl}_{3}$ salt 3(4-propionylphenoxy)phthalonitrile (1) (100 mg, $0.36 \mathrm{mmol})$ and a catalytic amount of DBU (1,8-diazabicyclo[5.4.0]undec-7ene) in $n$-hexanol $(2 \mathrm{~mL})$ was heated at $150{ }^{\circ} \mathrm{C}$ in a sealed glass tube for 8 hours. After cooling to room temperature, the product was cooled and precipitated by adding hexane and filtered. After being cleaned with methanol and then with diethylether several times. Finally, the product purified by chromatography over a silica gel column by chloroform-methanol solvent system. Finally and dried and vacuo.

2.2.2.1. 1(4),8(11),15(18),22(25)-Tetrakis (1-(4-hydroxyphenyl)propan-1-one)-phthalocyaninato copper(II) (2). The compound is excellent soluble in THF, $\mathrm{CHCl}_{3}, \mathrm{CH}_{2} \mathrm{Cl}_{2}$, DMF, DMSO. Yield of (2): $0.043 \mathrm{~g}$, (37\%). Anal. calcd for (\%) $\mathrm{C}_{72} \mathrm{H}_{56} \mathrm{CuN}_{8} \mathrm{O}_{8}$ (1168.70 g $\mathrm{mol}^{-1}$ ): C, 69.88; H, 4.14; Cu, 5.44; N, 9.59; O, 10.95; found: C, 70.02; H, 4.05; N, 9.42. FT-IR $\left(\nu_{\max } / \mathrm{cm}^{-1}\right): 3066,3030(\mathrm{H}-\mathrm{Ar}), 2972$, 2936, 2865 (H-Aliph.), 1733 (C=O), 1681 (Ar C=C), 1164 (Ar-OAr). UV-vis (THF): $\lambda_{\max } / \mathrm{nm}(\log \varepsilon): 687$ (4.71), 621 (4.11), 317 (4.42). ${ }^{1} \mathrm{H}-\mathrm{NMR}$ (DMSO-d ${ }_{6}$ ) ( $\left.\delta, \mathrm{ppm}\right):$ 8.95-8.41 (m, 12H, Pc-Ar-H), 7.68-7.11 (m, 16H, Ar-H), 3.82-2.23 (16H, m, $\left.-\mathrm{CH}_{2}\right), 1.39(12 \mathrm{H}, \mathrm{s}$, $-\mathrm{CH}_{3}$ ). MS (MALDI-MS, 2,5-dihydroxybenzoic acid as matrix): $1169.40[\mathrm{M}+\mathrm{H}]^{+}$.

2.2.2.2. 1(4),8(11),15(18),22(25)-Tetrakis (1-(4-hydroxyphenyl) propan-1-one)-phthalocyaninato zinc(II) (3). The compound is excellent soluble in THF, $\mathrm{CHCl}_{3}, \mathrm{CH}_{2} \mathrm{Cl}_{2}$, DMF, DMSO. Yield of (3): $0.032 \mathrm{~g}$, (32\%). Anal. calcd for (\%) $\mathrm{C}_{68} \mathrm{H}_{48} \mathrm{ZnN}_{8} \mathrm{O}_{8}(1170.57 \mathrm{~g}$ $\mathrm{mol}^{-1}$ ): C, 69.77; H, 4.13; N, 9.57; O, 10.93; Zn, 5.59; found: C, 69.10; H, 4.91; N, 9.85. FT-IR $\left(\nu_{\max } / \mathrm{cm}^{-1}\right): 3066$ (H-Ar), 2939, 2978 (H-Aliph.), $1681(\mathrm{C}=\mathrm{O}), 1590$ (Ar $\mathrm{C}=\mathrm{C}$ ), 1161-2 (Ar-O-Ar). UV-vis (THF): $\lambda_{\max } / \mathrm{nm}(\log \varepsilon): 689$ (4.79), 624 (4.21), 329 (4.56). ${ }^{1} \mathrm{H}^{-}$ 
NMR (DMSO-d ${ }_{6}$ ( $\left.\delta, \mathrm{ppm}\right):$ 8.97-8.50 (m, 12H, Pc-Ar-H), 7.76-7.23 (m, 16H, Ar-H), 3.88-2.35 (8H, m, $\left.-\mathrm{CH}_{2}\right), 1.35\left(12 \mathrm{H}, \mathrm{s},-\mathrm{CH}_{3}\right) . \mathrm{MS}$ (MALDI-MS, 2,5-dihydroxybenzoic acid as matrix): 1172.01 $[\mathrm{M}+\mathrm{H}]^{+}$.

2.2.2.3. 1(4),8(11),15(18),22(25)-Tetrakis (1-(4-hydroxyphenyl)propan-1-one)-phthalocyaninato indium(III) chloride (4). The compound is excellent soluble in THF, $\mathrm{CHCl}_{3}, \mathrm{CH}_{2} \mathrm{Cl}_{2}, \mathrm{DMF}$, DMSO. Yield of (4): $0.034 \mathrm{~g}$, (31\%). Anal. calcd for (\%) $\mathrm{C}_{68} \mathrm{H}_{48^{-}}$ $\mathrm{ClInN}_{8} \mathrm{O}_{8}\left(1255.43 \mathrm{~g} \mathrm{~mol}^{-1}\right): \mathrm{C}, 65.06 ; \mathrm{H}, 3.85 ; \mathrm{Cl}, 2.82 ; \mathrm{In}, 9.15 ; \mathrm{N}$, 8.93; O, 10.20; found: C, 65.22; H, 3.82; N, 9.02; FT-IR $\left(\nu_{\max } / \mathrm{cm}^{-1}\right)$ : 3068 (H-Ar), 2977, 2938 (H-Aliph.), 1726 (C=O), 1682, 1591 (Ar$\mathrm{C}=\mathrm{C}$ ), 1162 (Ar-O-Ar). UV-vis (THF): $\lambda_{\max } / \mathrm{nm}(\log \varepsilon): 702$ (4.21), 639 (3.56), 318 (4.09). ${ }^{1} \mathrm{H}-\mathrm{NMR}$ (DMSO-d 6 ) ( $\left.\delta, \mathrm{ppm}\right): 9.12-8.73$ (m, 12H, Pc-Ar-H), 7.87-6.98 (m, 16H, Ar-H), 3.09-2.37 (8H, m, $-\mathrm{CH}_{2}$ ), $1.69\left(12 \mathrm{H}, \mathrm{s},-\mathrm{CH}_{3}\right)$. MS (MALDI-MS, 2,5-dihydroxybenzoic acid as matrix): $1221.05[\mathrm{M}-\mathrm{CI}+\mathrm{H}]^{+}$.

2.2.2.4. 1(4),8(11),15(18),22(25)-Tetrakis (1-(4-hydroxyphenyl)propan-1-one)-phthalocyaninato cobalt(II) (5). The compound is excellent soluble in THF, $\mathrm{CHCl}_{3}, \mathrm{CH}_{2} \mathrm{Cl}_{2}$, DMF, DMSO. Yield of (5): $0.049 \mathrm{~g}$, (41\%). Anal. calcd for (\%) $\mathrm{C}_{72} \mathrm{H}_{56} \mathrm{CoN}_{8} \mathrm{O}_{8}(1164.09 \mathrm{~g}$ $\mathrm{mol}^{-1}$ ): C, 70.16; H, 4.16; Co, 5.06; N, 9.63; O, 11.00; found: C, 69.98; H, 4.27; N, 9.51; FT-IR $\left(\nu_{\max } / \mathrm{cm}^{-1}\right): 3062$ (H-Ar), 2934, 2865 (H-Aliph.), 1730 (C=O), 1677 (Ar-C=C), 1163 (Ar-O-Ar). UV-vis (THF): $\lambda_{\max } / \mathrm{nm}(\log \varepsilon$ ): 692 (4.71), 618 (4.20), 322 (4.63). MS (MALDI-MS, 2,5-dihydroxybenzoic acid as matrix): 1165.98 $[\mathrm{M}+\mathrm{H}]^{+}$.

\subsection{Cell lines}

Human breast adenocarcinoma (MCF-7), human bone osteosarcoma (MG63), and mouse fibroblast (L929) cell lines were supplied by the American Type Culture Collection (ATCC). Cell culture studies of human breast adenocarcinoma cell line (MCF-7), human bone osteosarcoma (MG63), and mouse fibroblast (L929) appropriate conditions and materials required in order to reproduce broth must be provided. In our study $10 \%$ fetal bovine serum (FBS), 1\% L-glutamine, 100 IU per $\mathrm{mL}$ penicillin and $10 \mathrm{mg} \mathrm{mL}^{-1}$ streptomycin in DMEM (low glucose) were used. Cancer cell lines in DMEM medium was produced in $95 \%$ humidity and $5 \% \mathrm{CO}_{2}$ incubator at $37{ }^{\circ} \mathrm{C}$.

\subsection{Cytotoxic assay of the synthesized compounds}

XTT test which was monitor azo aldehyde thioureas derivatives toxicity was applied on cancer cells. Firstly, the cancer cells were plated in 96-well plate $\left(10 \times 10^{4}\right.$ cells in each well) and the compounds were tested by 4 -fold diluting the starting mixture at four different concentration ranging from $(12.5 ; 50$; $75 ; 100 \mu \mathrm{M}) 24$ and $48 \mathrm{~h}$. Secondly, for determination of living cells $50 \mu \mathrm{L}$ XTT reagents were added to each well. After $4 \mathrm{~h}$, at $450 \mathrm{~nm}$ micro plate reader was used for absorbance measurements. Finally, the percentage of cell viability was calculated.

Anticancer activity of 6 azo chromophore containing new compounds were evaluated in breast cancer cell line and fibroblast cell line was used as control. Cells were exposed to four $(12.5 ; 25 ; 50 ; 100 \mu \mathrm{M})$ concentration range. XTT protocol was applied after 24 and $48 \mathrm{~h}$ and compared with control cell lines. The cell viability of control has been accepted as $100 \%$ in order to determined cell viability of compounds. When compounds of $[\mathrm{NiL}] \cdot \mathrm{H}_{2} \mathrm{O},[\mathrm{CoL}] \cdot 2 \mathrm{H}_{2} \mathrm{O},[\mathrm{ZnL}],[\mathrm{CuL}] \cdot 3 \mathrm{H}_{2} \mathrm{O}$ and as 24 and $48 \mathrm{~h}$ post-treatment the comparison of the antiproliferative effects were observed to be a more effective treatment for $24 \mathrm{~h}$. If the compounds $48 \mathrm{~h}$ after treatment was observed that more antiproliferative effect.

\subsection{Statistical analysis}

Data were expressed in the form of arithmetic mean \pm standard deviation $(x \pm \mathrm{SD})$. One way ANOVA and post hoc Tukey analyses were used to reveal the relationships between groups. The differences were accepted as significant for $p<0.05$. Statistical analysis were performed with SPSS for windows 22.0 package. All determinations were computed three times.

\subsection{Computational methodology}

2.6.1. Quantum chemical calculation method. Density functional theory is absolutely most widely used methodology for the prediction of chemical reactivity of molecules. Input files of complexes were created using Gauss view version 5.0.8. ${ }^{21}$ All the entry files of calculations were made by Gauss 09 Revision C.01 in TÜBİTAK-TR Grid. ${ }^{22}$ All calculations were fully optimized by using Density Functional Theory (DFT)/B3LYP ${ }^{23}$ and Hartree-Fock (HF) ${ }^{24}$ method. In calculations, Gen keyword was used LANL2DZ for metal atom and SDD, 6-311G and 3-21G basis set in gas phase for rest atoms were selected as basis sets in vacuum.

With the help of Density Functional Theory, chemical reactivity indices such as chemical hardness $(\eta)$, electronegativity $(\chi)$, chemical potential $(\mu)$ are defined as derivatives of the electronic energy $(E)$ and a constant external potential $\nu(r) \cdot{ }^{25-31}$ In the conceptual this theory, mentioned chemical properties are given as $^{32,33}$

$$
\begin{gathered}
\chi=-\mu=-\left(\frac{\partial E}{\partial N}\right)_{\nu(r)} \\
\eta=\frac{1}{2}\left(\frac{\partial E}{\partial N}\right)_{\nu(r)}=\frac{1}{2}\left(\frac{\partial^{2} E}{\partial N^{2}}\right)_{\nu(r)}
\end{gathered}
$$

In the conceptual Koopman's theorem, ${ }^{34}$ the negative of the highest occupied molecular orbital energy and negative of the lowest unoccupied molecular orbital energy corresponds to electron affinity and ionization energy $\left(-E_{\mathrm{LUMO}}=A\right.$ and $-E_{\text {Hомо }}=I$ ). As a result of Koopman's theorem, chemical potential and chemical hardness can be explained as: ${ }^{35}$

$$
\begin{gathered}
\mu=\frac{E_{\mathrm{LUMO}}+E_{\mathrm{HOMO}}}{2} \\
\eta=\frac{E_{\mathrm{LUMO}}-E_{\mathrm{HOMO}}}{2}
\end{gathered}
$$

According to Pearson, the global softness is defined as the inverse of the global hardness and this quantity is given as: ${ }^{.6,37}$ 


$$
S=\frac{1}{\eta}=\left(\frac{\partial N}{\partial \mu}\right)_{\nu(r)}
$$

Parr et al. by which the global electrophilicity index $(\omega)$ introduced are defined via eqn (6). With the help of this index, electrophilic power of a chemical compound is associated with its electronegativity and chemical hardness. Nucleophilicity $(\varepsilon)$ which is the inverse of the electrophilicity, is given via eqn (7).

$$
\begin{gathered}
\omega=\frac{\mu^{2}}{2 \eta}=\frac{\chi^{2}}{2 \eta} \\
\varepsilon=1 / \omega
\end{gathered}
$$

\section{Results and discussion}

\subsection{Synthesis and spectroscopic characterization}

The starting compounds, 3-(4-propionylphenoxy)phthalonitrile (1) were synthesized from 4-(4-hydroxyphenyl)butan-2-one and 3-nitrophthalonitrile (Scheme 1). The reaction was achieved through base-catalyzed aromatic displacement under $\mathrm{N}_{2}$ atmosphere by using $\mathrm{K}_{2} \mathrm{CO}_{3}$ as the base in dry DMF at $45{ }^{\circ} \mathrm{C}$ in 72 hours. The formation of the cobalt, copper, zinc and indium metallophthalocyanines $(2,5)$ were achieved by cyclotetramerisation reaction of the starting compounds (1) in $n$ hexanol and DBU using anhydrous $\mathrm{CoCI}_{2}$ or $\mathrm{CuCl}_{2}$ or $\mathrm{Zn}(\mathrm{Ac})_{2}$ or $\mathrm{InCl}_{3}$ salts (Scheme 1). The synthesized phthalocyanines (2-5) were purified by chromatography over a silica gel column by
$\mathrm{CH}_{2} \mathrm{Cl}_{2}$ /ethanol 50:1 mixture as eluent. All phthalocyanine compounds were soluble common organic solvents such as THF, $\mathrm{CHCl}_{3}, \mathrm{CH}_{2} \mathrm{Cl}_{2}, \mathrm{DMF}$, DMSO. After the cyclotetramerization reaction, the disappearance of the sharp $-\mathrm{C} \equiv \mathrm{N}$ vibration at around $2234 \mathrm{~cm}^{-1}$ for (1) proved the formation of the phthalocyanines (2-5) (Fig. 1). UV-vis spectra of the phthalocyanine complexes (2-5) exhibited characteristic absorptions in the Q-band region at around $680-700 \mathrm{~nm}$, attributed to the $\pi-\pi^{*}$ transition from the HOMO (highest occupied molecular orbital) to the LUMO (lowest unoccupied molecular orbital) of the $\mathrm{Pc}^{2-}$ ring, and in the $\mathrm{B}$ band region (UV region) at around 350-360 nm, arising from the deeper $\pi-\pi *$ transitions. The Qband absorptions of $\pi-\pi^{*}$ transition for all phthalocyanines (2-5) in THF were observed as a single band of high intensity at $687 \mathrm{~nm}(\mathrm{Q})$ for (2), $689 \mathrm{~nm}(\mathrm{Q})$ for (3), $702 \mathrm{~nm}(\mathrm{Q})$ for (4), $683 \mathrm{~nm}$ (Q) for (5) (Fig. 2). 3-(4-Propionylphenoxy)phthalonitrile (1) was also characterized by Mass Spectrometry. Mainly protonated ion peak of (1) was at high intensity beside the potassium adduct peak which was compatible with calculated values for (1) (Fig. 3).

\subsection{Aggregation studies}

The aggregation of phthalocyanines affects their application properties such as photophysical, electrochemical and spectroscopic properties. So, the investigation of aggregation properties of phthalocyanine are important. Aggregation is dependent on the nature of the solvent, concentration, nature of substituents, complex metal ions and temperature. ${ }^{38}$ In this study, the aggregation behaviors of (2-5) were examined in THF (Fig. 4). All synthesized phthalocyanines did not show any<smiles>CCC(=O)c1ccc(Oc2cccc(C#N)c2C#N)cc1</smiles>

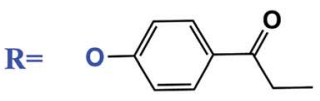

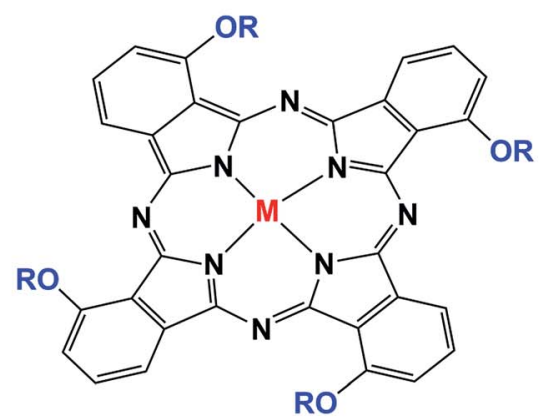

$\mathrm{M}=\mathrm{Cu}(2), \mathrm{Zn}(3), \operatorname{InCl}(4), \operatorname{Co}(5)$

Scheme 1 (i) 1-(4-Hydroxyphenyl)propan-1-one and 3-nitrophthalonitrile, $\mathrm{K}_{2} \mathrm{CO}_{3}, \mathrm{DMF}, 40{ }^{\circ} \mathrm{C}, 3$ days. (ii) 3-(4-Hydroxyphenyl)butan-2-one metal salts $\left(\mathrm{CuCl}_{2}\right.$ or $\mathrm{Zn}(\mathrm{Ac})_{2}$ or $\mathrm{InCl}_{3}$ or $\left.\mathrm{CoCl}_{2}\right), \mathrm{DBU}, n$-hexanol, $160^{\circ} \mathrm{C}$. 


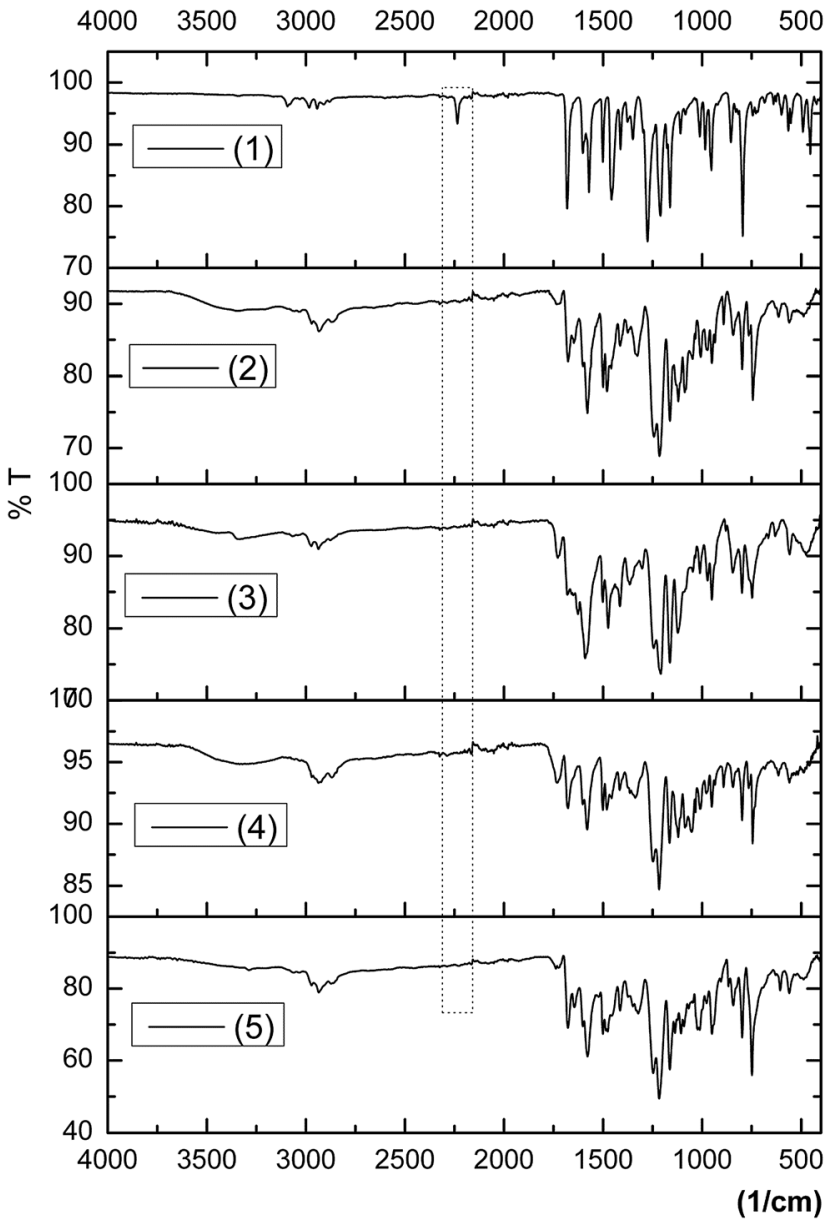

Fig. 1 The FT-IR spectra of the synthesized phthalocyanines (2-5).

aggregation behaviors in THF. When the concentrations of the Pc increased, the intensity of absorption of the Q-band also increased (the Lambert-Beer law was obeyed), and new blue or red shifted band formation were not observed.

\subsection{Fluorescence measurements}

Fluorescence quantum yields were calculated using eqn (8)

$$
\Phi_{\mathrm{s}}=\Phi_{\mathrm{ref}}\left(\frac{F_{\mathrm{s}}}{F_{\mathrm{ref}}}\right)\left(\frac{A_{\mathrm{ref}}}{A_{\mathrm{s}}}\right)\left(\frac{n_{\mathrm{s}}^{2}}{n_{\mathrm{ref}}{ }^{2}}\right)
$$

where $F_{\mathrm{s}}$ and $F_{\text {ref }}$ are area under the fluorescence emission spectra measured of sample and standard, respectively, $A_{\mathrm{s}}$ and $A_{\text {ref }}$ are absorbances at the same excitation wavelength of sample and standard, respectively, $n_{\mathrm{s}}$ and $n_{\text {ref }}$ are refractive indexes of solvent used for sample and standard and $\Phi_{\text {ref }}$ is quantum yield of standard. ZnPc in THF $\left(\Phi_{\mathrm{F}}=0.32\right)^{39}$ for Qband region were employed as the standards. Both the sample and standard were excited at the same wavelength.

The fluorescence behaviors of (2-4) were studied in THF. The absorption, fluorescence emission and excitation spectra for (24) were shown in Fig. 5. Fluorescence emission peaks were observed at $705 \mathrm{~nm}$ for (2), $704 \mathrm{~nm}$ for (3) and $721 \mathrm{~nm}$ for (4) in THF, respectively. The $\mathrm{Q}$ bands of the non-peripheral

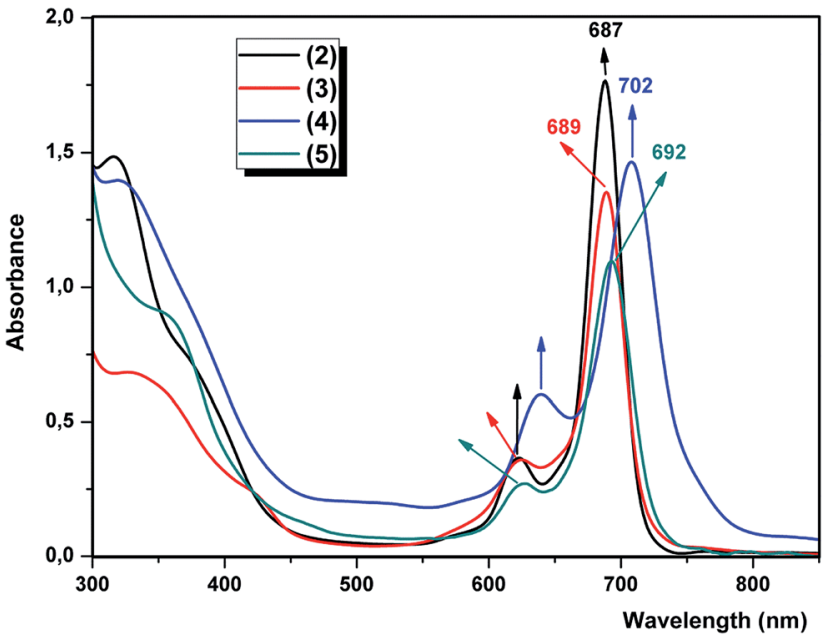

Fig. 2 The absorbance spectra of the synthesized phthalocyanines (2-5) solved in THF.

substituted phthalocyanines' luminescent spectra are bathochromic shifted when compared to the corresponding peripheral substituted phthalocyanines. The red shifts observed in emission maxima are 40-60 $\mathrm{nm}$ in comparison with peripheral substituted phthalocyanines. ${ }^{40}$ Fluorescence excitation peaks were observed at $694 \mathrm{~nm}$ for (2), $687 \mathrm{~nm}$ for (3) and $698 \mathrm{~nm}$ for (4) in THF, respectively. Absorption spectra of (2-4) indicated characteristic one absorption band at $\mathrm{Q}$ band region that was at $687 \mathrm{~nm}$ for (2), $689 \mathrm{~nm}$ for (3) and $702 \mathrm{~nm}$ for (4) in THF, respectively. Absorption and fluorescence excitation spectra of (2-4) are very similar and mirror images of their emission spectrum in the solvent of THF. The observed Stokes shifts for (2-4) were within the region 15-19 nm in THF which was typical for phthalocyanines. ${ }^{41,42}$ Absorption, fluorescence excitation and emission peaks for (2-4) in THF were listed in Table 1.

Considering different metal effects on $\Phi_{\mathrm{F}}$ values, the highest $\Phi_{\mathrm{F}}$ value (0.115) was obtained for the complex (3) containing closed shell diamagnetic ions, such as $\mathrm{Zn}^{2+}$ which is important for PDT. The metal of $\mathrm{Zn}^{2+}$ have been proved as highly promising photosensitizers for PDT (photodynamic therapy) due to their intense absorption in the red region of the visible light. ${ }^{43,44}$

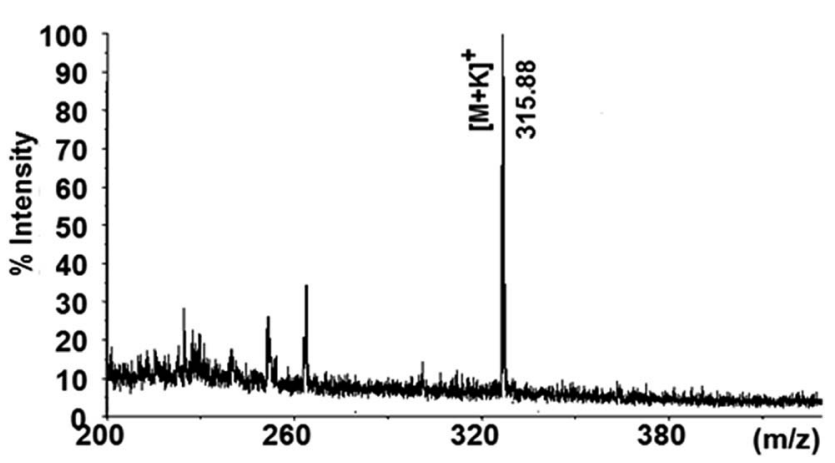

Fig. 3 The mass spectrum of the 3-(4-propionylphenoxy)phthalonitrile (1). 

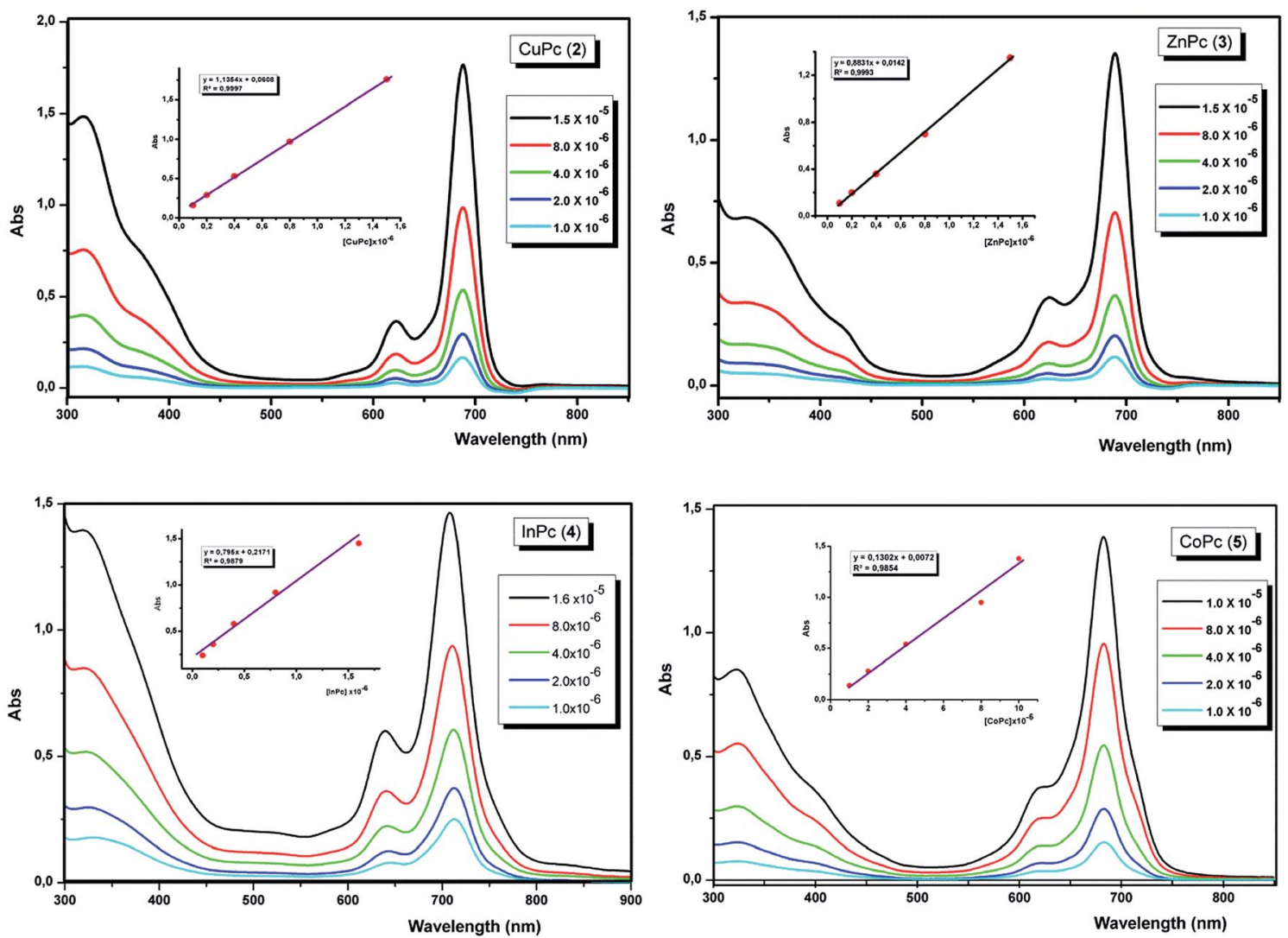

Fig. 4 Absorbance changes of the phthalocyanines (2-5) in THF at different concentrations (inset: plot of absorbance versus concentration).

The other obtained $\Phi_{\mathrm{F}}$ values were quite low (0.006) for (2) and $(0.045)$ for (4) due to the heavy atom effect. ${ }^{45}$ The $\Phi_{\mathrm{F}}$ values of the studied phthalocyanine compounds (2-4) were lower than those of unsubstituted zinc(II) phthalocyanine ( $\mathrm{ZnPc}$ ) in THF. The decrease in the $\Phi_{\mathrm{F}}$ values is because of the substituents. This implies that the presence of non-peripheral 1-(4-hydroxyphenyl) propan-1-one substituents caused some fluorescence quenching of the parent (2-4).

\subsection{Anticancer activity}

In this work, anticancer activities of compounds of phthalocyanine were studied on MCF-7, MG63, and L929 cell lines. Anticancer activity of the synthesized compounds were investigated and results are presented in Fig. 6-8. Cells were studied using four different concentrations $(12.5 ; 50 ; 75 ; 100 \mu \mathrm{M})$. XTT protocol was applied after $24 \mathrm{~h}$ and $48 \mathrm{~h}$. Viability of control cells has been accepted as $100 \%$. $\mathrm{IC}_{50}$ values were calculated for MCF-7, MG63, and L929 cell lines for 24 and $48 \mathrm{~h}$ (Table 2).

The compounds were applied to three different types of cell lines on a $24 \mathrm{~h}$ incubation. Complex (5) acted well on MCF-7 and MG63 cell lines. It is not suitable for application to cancer cell lines due to its complex toxicity.

Complex (5) showed anticancer effect on MCF-7 and MG63 cell lines. The complex (4) is not suitable for application to cancer cell lines from the toxic nature of the compound on L929 cell lines. Complex (3) both MCF-7 and MG63 cell lines were anticancer effective; the compound is most likely to have more of an anticancer effect on the MCF-7 cell lines. Complex (2) does not have anticancer effect for MG63 cell lines, whereas MCF-7 cell lines has anticancer effect.

\subsection{Computational results}

3.5.1. Quantum chemical calculations. All synthesized phthalocyanines were investigated by quantum chemical studies. The obtained result in this study are given in detail below by Gaussian Soft Ware. Chemical reactivity parameter such as $E_{\text {HOMO, }} E_{\text {LUMO }}, \Delta E$ (HOMO-LUMO energy gap), chemical hardness, softness, electronegativity, proton affinity, electrophilicity and nucleophilicity are important and useful tools to compare activity of molecules. The molecular reactivity of the studied molecules in this paper was investigated and compared with to analysis of Frontier molecular orbitals. The energy of HOMO is associated with the electron donating ability of molecule. High energy value of HOMO state show prone to donate electrons to appropriate acceptor molecules having low energy and empty molecular orbital. In the light of this information, HOMO energy level is an indicator of electron donating abilities of molecules. Chemical hardness is defined the resistance against electron cloud polarization or deformation of chemical species. ${ }^{46}$ Hard and Soft Acid-Basis (HSAB) ${ }^{47,48}$ and Maximum Hardness Principles (MHP) ${ }^{49}$ based on chemical hardness concept that are very beneficial in terms of estimating 

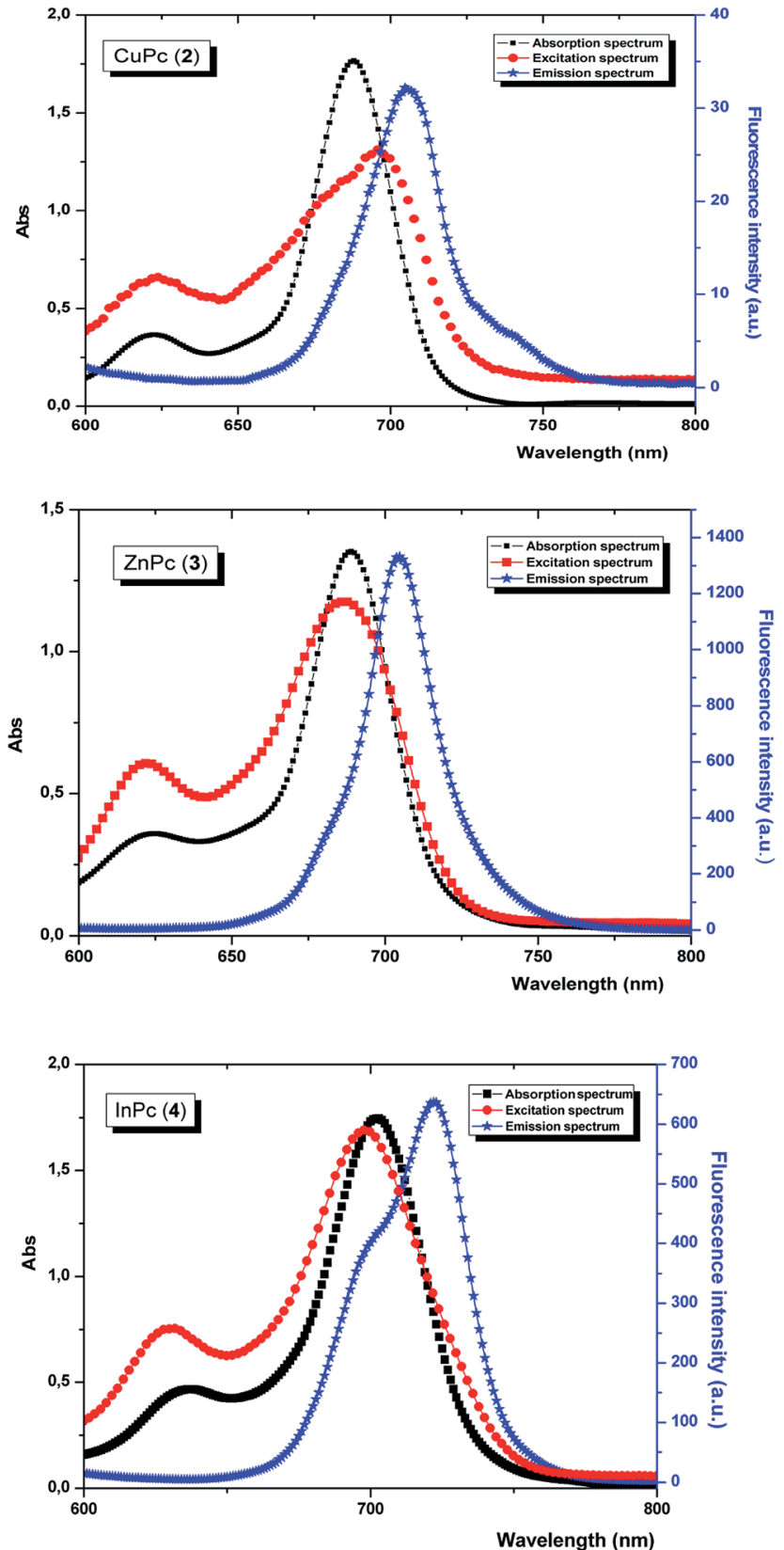

Fig. 5 Electronic absorption, excitation, and emission spectra for (24) in THF.

the directions of chemical reactions. As can be understood from this definition chemical hardness, softness and $\Delta E$ that are quantum chemical parameters in theoretical chemistry, are

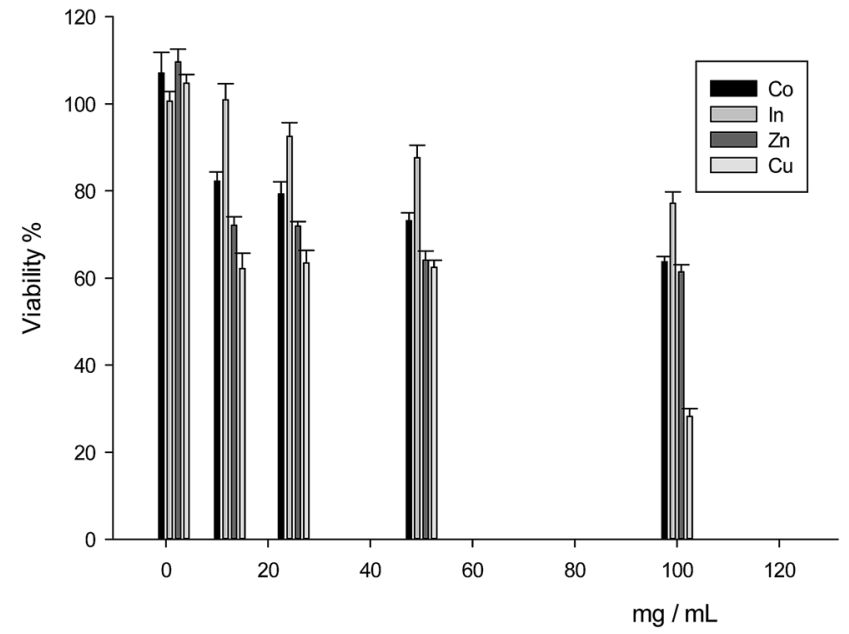

Fig. 6 MCF-7 cell line.

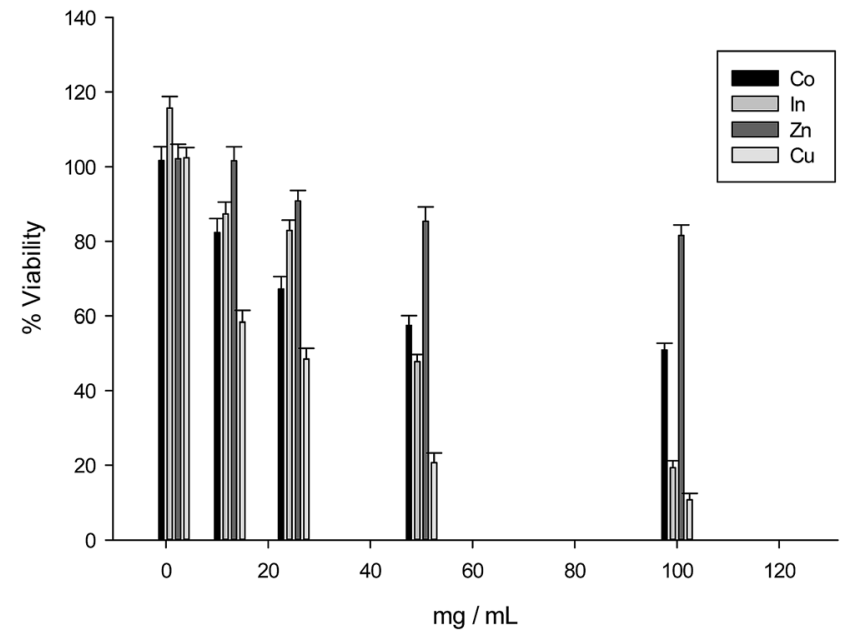

Fig. 7 L929 cell line.

associated with each other. ${ }^{50}$ As a result of Koopman's theorem, both softness and hardness are given based on HOMO and LUMO orbital energies. Hard molecules that have high HOMOLUMO energy gap, cannot act as good active molecule. On the other hand, soft molecules that have low HOMO-LUMO energy gap, are good active molecule. ${ }^{51,52}$ For the reason that they can very easy give electron to metals. As a result of calculated HOMO and LUMO energy levels given in Tables 3 and 4 for studied compounds. Furthermore, the order of increasing reactivity is: $\mathbf{5}$ $>2>3 \gg 4$.

Table 1 Spectral parameters of the complexes (2-4) in THF

\begin{tabular}{llllllll}
\hline Solvents & Compounds & $\begin{array}{l}\text { Q band, } \lambda_{\max }, \\
(\mathrm{nm})\end{array}$ & $\log \varepsilon$ & $\begin{array}{l}\text { Excitation, } \\
\lambda_{\text {Ex }},(\mathrm{nm})\end{array}$ & $\begin{array}{l}\text { Emission, } \lambda_{\text {Ex }}, \\
(\mathrm{nm})\end{array}$ & $\begin{array}{l}\text { Stokes shift, } \\
\Delta_{\text {Stokes}},(\mathrm{nm})\end{array}$ & $\begin{array}{l}\text { Fluorescence spectra } \\
\text { and quantum, } \Phi_{\mathrm{F}}\end{array}$ \\
\hline \multirow{2}{*}{ THF } & $(2)$ & 687 & 4.71 & 694 & 705 & 18 & 0.006 \\
& $(3)$ & 689 & 4.79 & 687 & 704 & 15 & 0.115 \\
& $(4)$ & 702 & 4.21 & 698 & 721 & 19 & 0.045
\end{tabular}




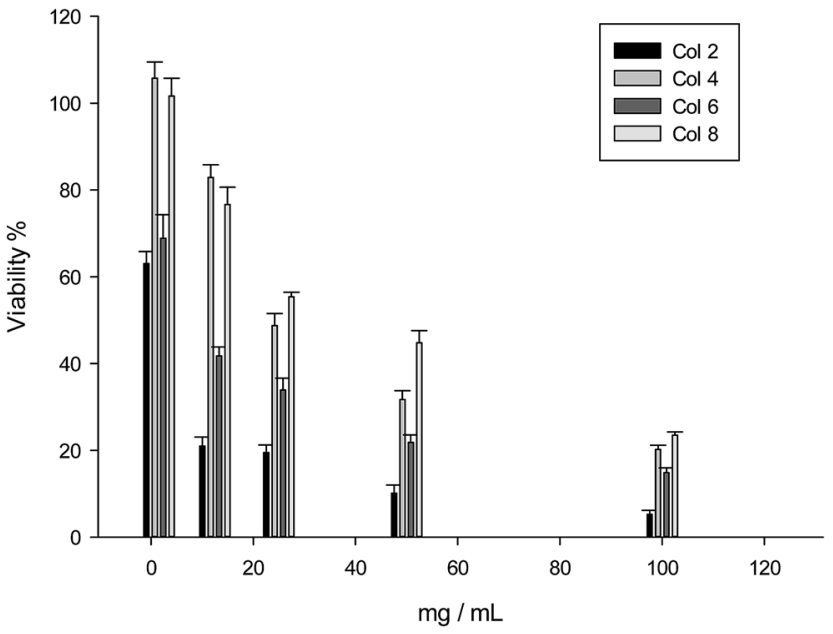

Fig. 8 Mg63 cell line.

Table $2 \quad I_{50}$ values of phthalocyanine complexes

\begin{tabular}{lrrr}
\hline Compounds & L929 & MCF-7 & MG63 \\
\hline$(5)$ & 19.53 & 8.85 & 12.14 \\
$(4)$ & 39.57 & 44.67 & 22.06 \\
$(3)$ & 26.94 & 5.80 & 20.28 \\
$(2)$ & 15.70 & 12.48 & 15.80
\end{tabular}

In quantum chemical studies, the electrophilicity index $(\omega)$ is a very important parameter that indicates the tendency of the active molecule to accept the electrons. As it is well known that this quantity is constantly used in the analysis of chemical reactivity of molecules. Nucleophilicity $(\varepsilon)$ is a physically the inverse of electrophilicity $(1 / \omega)$. For the reason that is should be stated that a molecule have large electrophilicity value that is ineffective of activity of molecule although a molecule that have large nucleophilicity value is a good activity of molecule. As it is well known that molecular electrophilicity are based on both molecular electronegativity and molecular hardness.

The Gibbs free energy $(\Delta G)$ was calculated using below equation:

$$
\Delta E=E_{\mathrm{M}-\mathrm{L} \text { complex }}-\left[E_{\mathrm{M}^{2+}}+\sum E_{\text {ligand }}\right]
$$

where $E_{\mathrm{M}-\mathrm{L} \text { complex }}$ is the energy of the metal complex, $E_{\text {ligand }}$ is the energy of the ligand and $E_{\mathrm{M}^{2+}}$ is energy of the metal ion. ${ }^{53}$ As it is well known three possibilities for Gibbs free energy.
Table $4 E_{\text {Hомо, }} E_{\text {LUMO }}$ and zero point energy for metal atoms $\left(E_{\mathrm{v}}\right)$

\begin{tabular}{llll}
\hline & & B3LYP & Hartree-Fock \\
\hline $\mathrm{Cu}^{2+}$ & $E_{\text {HOMO }}$ & -32.33173 & -39.96949 \\
& $E_{\text {LUMO }}$ & -20.06556 & -15.84776 \\
& Thermal free energies $(G)$ & -5308.47607 & -5282.40567 \\
$\mathrm{Co}^{2+}$ & $E_{\text {HOMO }}$ & -29.31397 & -36.02571 \\
& $E_{\text {LUMO }}$ & -25.61754 & -15.07033 \\
& Thermal free energies $(G)$ & -3918.68202 & -3897.02167 \\
$\mathrm{Zn}^{2+}$ & $E_{\text {HOMO }}$ & -36.16857 & -41.22857 \\
& $E_{\text {LUMO }}$ & -19.93250 & -16.23553 \\
$\mathrm{InCl}^{2+}$ & Thermal free energies $(G)$ & -1759.01736 & -1704.89964 \\
& $E_{\text {HOMO }}$ & -7.07066 & -9.29412 \\
& $E_{\text {LUMO }}$ & -2.14700 & 0.29688 \\
& Thermal free energies $(G)$ & -460.56912 & -451.93191
\end{tabular}

First, if $\Delta G$ is negative for a process then the process is spontaneous and it will occur in the forward direction. Second, if $\Delta G$ is zero for a process then the process is in equilibrium state. The reaction will not take place. Third, if $\Delta G$ is positive for a process then the reaction doesn't proceed in the forward direction. It may occur in the reverse direction. We see in Table 5. All of metal-complexes is calculated the Gibbs free energy $(\Delta G)$ in the Table 5 . The reaction with the negative high Gibbs free energy value is easier to achieve than the others. The order in which the reactions are spontaneous is as follows: $4 \gg 3>2>5$.

It is clear known that the figure of molecular electrostatic potential (ESP) of six molecules givens an indication of the total charge distribution (electron + nuclei) of the molecule and correlates with dipole moments, electronegativity, partial charges and chemical reactivity of six molecules. It provides that a visual method to understand the relative polarity of the molecules. An electron density isosurface of six molecules mapped with electrostatic potential surface the size, shape, charge density and site of chemical reactivity of molecules. ${ }^{30}$

The different value of the electrostatic potential represented by different colors: red represents the region of the most negative electrostatic potential, blue represent the regions of the most positive electrostatic potential and green represents the region of zero potential. The potential increases in the order red $<$ orange $<$ yellow $<$ green $<$ blue. From the light of the result given in the mapped have been plotted for title molecules in 6$311++\mathrm{G}^{* *}$ basis set using the computer software gauss view (Fig. 9).

Table 3 Calculated quantum chemical parameters for 3-(4-propionylphenoxy)phthalonitrile $\left(E_{\mathrm{v}}\right)$

\begin{tabular}{|c|c|c|c|c|c|c|c|c|c|c|}
\hline B3LYP/SDD & -6.04315 & -3.66268 & 6.04315 & 3.66268 & 2.38047 & 1.19024 & 0.84017 & 4.85292 & 9.89334 & 0.10108 \\
\hline B3LYP/6-311G & -6.11907 & -3.71085 & 6.11907 & 3.71085 & 2.40823 & 1.20411 & 0.83049 & 4.91496 & 10.03096 & 0.09969 \\
\hline $\mathrm{HF} / \mathrm{SDD}$ & -9.02282 & -0.28980 & 9.02282 & 0.28980 & 8.73302 & 4.36651 & 0.22902 & 4.65631 & 2.48268 & 0.40279 \\
\hline $\mathrm{HF} / 6-311 \mathrm{G}$ & -8.89139 & -0.16409 & 8.89139 & 0.16409 & 8.72730 & 4.36365 & 0.22917 & 4.52774 & 2.34900 & 0.42571 \\
\hline $\mathrm{HF} / 3-21 \mathrm{G}$ & -8.66227 & -0.08055 & 8.66227 & 0.08055 & 8.58172 & 4.29086 & 0.23305 & 4.37141 & 2.22673 & 0.44909 \\
\hline
\end{tabular}


Table 5 The Gibbs free energy $(\Delta G)$ for complexes

\begin{tabular}{|c|c|c|c|c|c|c|}
\hline Compounds & B3LYP/SDD & B3LYP/6-311G & B3LYP/3-21G & $\mathrm{HF} / \mathrm{SDD}$ & $\mathrm{HF} / 6-311 \mathrm{G}$ & $\mathrm{HF} / 3-21 \mathrm{G}$ \\
\hline (2) & $-9238,99403$ & $-9208,18473$ & 104326,65447 & $-9214,24622$ & $-9183,11781$ & $-9076,81458$ \\
\hline (3) & $-11342,56780$ & $-11309,73099$ & $-11021,04892$ & $-11283,07695$ & $-11249,42331$ & $-10961,95814$ \\
\hline (5) & $-8130,07629$ & $-8118,95077$ & $-7948,46999$ & $-8102,50607$ & $-8071,36974$ & $-8457,79356$ \\
\hline
\end{tabular}
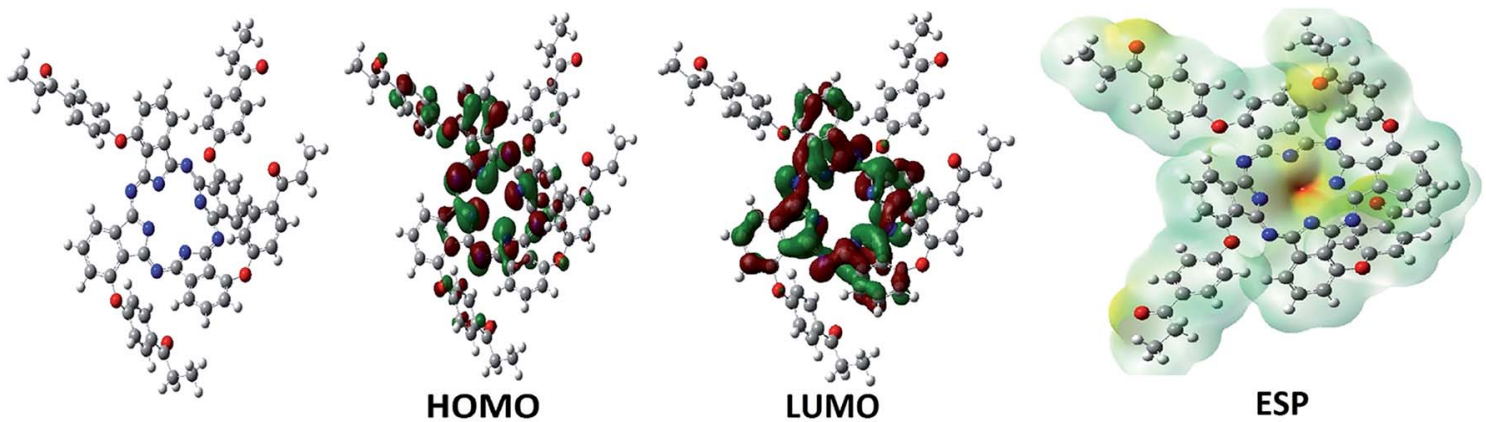

Fig. 9 The optimized structures, HOMO, LUMO and electrostatic potential structures of synthesized phthalocyanines molecules using DFT/ B3LYP/6-31++G(d,p).

\section{Conclusion}

In this paper, we have synthesized and characterized the phthalocyanines (M = Cu(II) (2), Zn(II) (3), In(III) (4) and Co(II) (5)) which is nonperipherally tetra-substituted with 1-(4-s hydroxyphenyl)propan-1-one. In THF, the fluorescence quantum yields $\Phi_{\mathrm{F}}$ for complexes (2-4) were found to be lower than unsubstituted zinc(II) phthalocyanine (ZnPc) in THF. This implies that the presence of non-peripheral 1-(4-hydroxyphenyl) propan-1-one substituents caused some fluorescence quenching of the parent (2-4). The most suitable compound for the MCF-7 cell line from the four compounds is the complex (3); the anticancer effect of the complex (5) in the MG63 cell line is good. The synthesized azo chromophore containing compounds might be potentially useful in the field of cancer treatment. Major problem that is chemotherapeutic agents are side-effect, which kill both cancerous and normal cells since they are not selective. So there is new agent for cancer therapeutic. Our studied showed anticancer effect on MCF-7 and MG63 cell line. Complex (3) both MCF-7 and MG63 cell lines were anticancer effective. Complex (3) was applied to MCF-7 cell line and cell viability decreased from $100 \%$ to $60 \%$.

\section{Conflicts of interest}

There are no conflicts to declare.

\section{References}

1 A. Urruticoechea, R. Alemany, J. Balart, A. Villanueva, F. Vinals and G. Capella, Curr. Pharm. Des., 2010, $16,3$.

2 Phthalocyanines: properties and applications, ed. C. C. Leznoff and A. B. P. Lever, New York, 1996, vol. 4.
3 S. Chaure, D. Paul, P. Vadagma and A. K. Ray, J. Hazard. Mater., 2010, 173, 253.

4 M. L. Rodriguez-Mendez and J. A. De Saja, J. Porphyrins Phthalocyanines, 2009, 13, 606.

5 X. Chen, X. Hu, L. An, N. Zhang, D. Xia, X. Zuo and X. Wang, Electrocatalysis, 2014, 5, 68.

6 K. Mandal, D. Jana, B. K. Ghorai and N. R. Jana, J. Phys. Chem. C, 2016, 120, 5196.

7 S. Swavey and M. Tran, Porphyrin and Phthalocyanine Photosensitizers as PDT Agents: A New Modality for the Treatment of Melanoma, In Tech, Rijeka, Croatia, 2013, p. 253.

8 Ş. Özçelik, G. K. Karaoğlan, G. Gümrükçü, A. Erdogmus and A. Gül, J. Organomet. Chem., 2014, 769, 17.

9 H. Ali and J. E. van Lier, Chem. Rev., 1999, 99, 2379.

10 A. T. Bilgiçli, M. Durdașoglu, E. Kırbaç, M. N. Yarasir and M. Kandaz, Polyhedron, 2015, 100, 1-9.

11 B. Kiyak, A. A. Esenpınar and M. Bulut, Polyhedron, 2015, 90, 183-196.

12 M. S. Ağırtaş, Dyes Pigm., 2008, 79, 247.

13 E. N. Kaya, M. Durmus and M. Bulut, J. Organomet. Chem., 2014, 774, 94.

14 A. Günsel, M. N. Yaraşır, M. Kandaz and A. Koca, Synthesis, Polyhedron, 2010, 29, 3394.

15 P. G. Blassan, A. Heidi and M. H. Nanjundaswamy, Photodiagn. Photodyn. Ther., 2017, 19, 266.

16 K. H. Tamarisk, A. Heidi and J. C. Marianne, Photodiagn. Photodyn. Ther., 2012, 9, 215.

17 O. Ogbodu, L. L. Janice, P. Earl and T. Nyokong, Synth. Met., 2015, 204, 122.

18 J. C. Maruzzela and P. A. Henry, J. Am. Pharm. Assoc., 1958, 47, 294. 
19 A. J. Papa, in Kirk-Othmer encyclopedia of chemical technology, ed. M. Grayson, H. F. Mark, D. F. Othmer, C. G. Overberger and G. T. Seaborg, John Wiley \& Sons, New York, 1981, 13, p. 894.

20 J. Kling, Eur. Mol. Biol. Organ. J., 2007, 8(10), 903.

21 Gauss View 5.0, Gaussian Inc, Wallingford, CT, USA, 2009.

22 M. J. Frisch, G. W. Trucks, H. B. Schlegel, G. E. Scuseria, M. A. Robb, J. R. Cheeseman, G. Scalmani, V. Barone, B. Mennucci, G. A. Petersson, H. Nakatsuji, M. Caricato, X. Li, H. P. Hratchian, A. F. Izmaylov, J. Bloino, G. Zheng, J. L. Sonnenberg, M. Hada, M. Ehara, K. Toyota, R. Fukuda, J. Hasegawa, M. Ishida, T. Nakajima, Y. Honda, O. Kitao, H. Nakai, T. Vreven, J. A. Montgomery Jr, J. E. Peralta, F. Ogliaro, M. Bearpark, J. J. Heyd, E. Brothers, K. N. Kudin, V. N. Staroverov, T. Keith, R. Kobayashi, J. Normand, K. Raghavachari, A. Rendell, J. C. Burant, S. S. Iyengar, J. Tomasi, M. Cossi, N. Rega, J. M. Millam, M. Klene, J. E. Knox, J. B. Cross, V. Bakken, C. Adamo, J. Jaramillo, R. Gomperts, R. E. Stratmann, O. Yazyev, A. J. Austin, R. Cammi, C. Pomelli, J. W. Ochterski, R. L. Martin, K. Morokuma, V. G. Zakrzewski, G. A. Voth, P. Salvador, J. J. Dannenberg, S. Dapprich, A. D. Daniels, O. Farkas, J. B. Foresman, J. V. Ortiz, J. Cioslowski and D. J. Fox, Gaussian, Inc., Wallingford CT, 2010.

23 T. Yanai, D. P. Tew and N. C. Handy, Chem. Phys. Lett., 2004, 39, 351.

24 A. D. Becke, J. Chem. Phys., 1993, 98, 1372.

25 S. Kaya, B. Tüzün, C. Kaya and I. B. Obot, J. Taiwan Inst. Chem. Eng., 2016, 58, 528.

26 S. Kaya, C. Kaya, L. Guo, F. Kandemirli, B. Tüzün, İ. Uğurlu, L. H. Madkour and M. Saraçoğlu, J. Mol. Liq., 2016, 219, 497.

27 S. Kaya, P. Banerjee, S. K. Saha, B. Tüzün and C. Kaya, RSC Adv., 2016, 6(78), 74550.

28 I. B. Obot, S. Kaya, C. Kaya and B. Tüzün, Phys. E, 2016, 80, 82.

29 I. B. Obot, S. Kaya, C. Kaya and B. Tüzün, Res. Chem. Intermed., 2016, 42(5), 4963.

30 B. Tüzün, Journal of New Results in Science, 2014, 5, 67.
31 S. Kaya, L. Guo, C. Kaya, B. Tüzün, I. B. Obot, R. Touir and N. Islam, J. Taiwan Inst. Chem. Eng., 2016, 65, 522.

32 H. Chermette, J. Comput. Chem., 1999, 20, 129.

33 R. G. Parr and P. K. Chattaraj, J. Am. Chem. Soc., 1991, 113, 1854.

34 T. Koopmans, Physica, 1933, 1, 104.

35 N. Islam and D. C. Ghosh, Int. J. Quantum Chem., 2011, 109, 917.

36 W. Yang, C. Lee and S. K. Ghosh, J. Phys. Chem., 1985, 89, 5412.

37 W. Yang and R. G. Parr, Proc. Natl. Acad. Sci. U. S. A., 1985, 82, 6723.

38 H. Enkelkamp and R. J. M. Nolte, J. Porphyrins Phthalocyanines, 2000, 4, 454.

39 P. Zimcik, V. Novakova, K. Kopecky, M. Miletin, R. Z. Uslu Kobak and E. Svandrlikova, Inorg. Chem., 2012, 51, 4215.

40 S. Makhseed, M. Al-Sawah, J. Samuel and H. Manaa, Tetrahedron Lett., 2009, 50, 165.

41 I. Ozçeşmeci, A. K. Burat and Z. A. Bayır, J. Organomet. Chem., 2014, 750, 125.

42 Y. Zorlu, F. Dumoulin, M. Durmus and V. Ahsen, Tetrahedron, 2010, 66, 3248.

43 E. Kirbaç, G. Y. Atmaca and A. Erdoğmuş, J. Organomet. Chem., 2014, 752, 115.

44 I. Acar, Z. Bıyıklığlu, M. Durmus and H. Kantekin, J. Organomet. Chem., 2012, 65, 708.

45 I. Ozçeşmeci, A. Gelir and A. Gül, J. Lumin., 2014, 147, 141. 46 G. Makov, J. Phys. Chem., 1995, 99, 9337.

47 R. G. Pearson, J. Am. Chem. Soc., 1963, 85, 3533.

48 R. G. Pearson, J. Chem. Educ., 1968, 45, 581.

49 I. B. Obot, N. O. Obi-Egbedi and A. O. Eselo, Ind. Eng. Chem. Res., 2011, 50, 2098.

50 R. G. Pearson, J. Chem. Educ., 1987, 64, 561.

51 A. Üngördü and N. Tezer, J. Mol. Graphics Modell., 2017, 74, 256.

52 A. Üngördü and N. Tezer, J. Saudi Chem. Soc., 2017, 21, 837. 53 A. C. Ekennia, A. A. Osowole, L. O. Olasunkanmi, D. C. Onwudiwe and E. E. Ebenso, Res. Chem. Intermed., 2017, 43(7), 3787. 